Check for updates

Cite this: RSC Adv., 2020, 10, 43

Received 7th November 2019 Accepted 9th December 2019

DOI: 10.1039/c9ra09253f

rsc.li/rsc-advances

\section{The efficient degradation of organic pollutants in an aqueous environment under visible light irradiation by persulfate catalytically activated with kaolin- $\mathrm{Fe}_{2} \mathrm{O}_{3}$}

\begin{abstract}
Qianqian He, ${ }^{a}$ Chunsheng Xie, (D) ${ }^{* b}$ Dexin Gan ${ }^{\star a}$ and Chun Xiao ${ }^{b}$
In recent years, persulfate (PS) has been widely studied as a promising oxidant. In this work, a new $\mathrm{K}-\mathrm{Fe}_{2} \mathrm{O}_{3}$ catalyst was synthesized via a facile impregnation method. $\mathrm{K}-\mathrm{Fe}_{2} \mathrm{O}_{3}$ samples were utilized as heterogeneous photocatalysts for the degradation of aquatic organic pollutants (rhodamine, RhB, and ciprofloxacin, CIP). The catalysts showed excellent catalytic activity in the presence of PS under the irradiation of visible light, owing to the generation of $\mathrm{SO}_{4}{ }^{-}$and $\cdot \mathrm{OH}$ active radicals. The degradation ratio and $\mathrm{COD}$ removal ratio for $\mathrm{RhB}$ were $99.8 \%$ and $88.3 \%$. More importantly, the system retained a high degradation activity for $\mathrm{RhB}$ within a wide operating $\mathrm{pH}$ range of 2.9-10. The results of cycling degradation experiments confirmed that the $\mathrm{K}-\mathrm{Fe}_{2} \mathrm{O}_{3}$ catalyst was stable and recoverable. Large-scale experiments for treating dye wastewater under irradiation by natural sunlight were carried out, showing that this study can provide a new perspective for the treatment of wastewater.
\end{abstract}

\section{Introduction}

As a new type of advanced oxidation process (AOP), the activation of persulfate (PS) has recently gained more interest, and it has been used to treat dyes and toxic substances in wastewater thanks to its easy operation, high reactivity and low cost. ${ }^{1-5}$ Heat, ${ }^{6}$ UV light irradiation, ${ }^{7}$ microwaves,${ }^{8}$ and transition-metal ions $^{9}$ have been applied to enhance the production of oxidizing species (sulfate radical, $\mathrm{SO}_{4}{ }^{-}$). Iron ions have widely been used in the system of activation for persulfate due to their non-toxicity and environmental friendliness. Therefore, the addition of iron ions is most common during the activation reaction, which is very similar to the Fenton reaction, so some researchers also call it a Fenton-like reaction. ${ }^{10}$ Many researchers have found that a system composed of ferric ions and PS had high photocatalytic activity. The $\mathrm{Fe}^{2+} / \mathrm{PS}$ system can catalyze PS to produce $\mathrm{SO}_{4}{ }^{--}$, and $\mathrm{SO}_{4}{ }^{--}$has a higher redox potential than most other free radicals $\left(E^{0}=2.5-3.1 \mathrm{~V}\right)$, as shown in eqn (1). ${ }^{11}$ Then, $\mathrm{OH}^{*}$ is formed after further reaction (eqn (2) and (3)). ${ }^{12}$ Therefore, the $\mathrm{Fe}^{2+} / \mathrm{PS}$ system exhibited a capability for the oxidative removal of organic pollutants. ${ }^{13}$

$$
\begin{gathered}
\mathrm{S}_{2} \mathrm{O}_{8}{ }^{2-}+\mathrm{Fe}^{2+} \rightarrow \mathrm{SO}_{4}{ }^{2-}+\mathrm{SO}_{4}{ }^{--}+\mathrm{Fe}^{3+} \\
\mathrm{SO}_{4}{ }^{\cdot-}+\mathrm{H}_{2} \mathrm{O} \rightarrow \mathrm{SO}_{4}{ }^{2-}+\mathrm{OH}^{\cdot}+\mathrm{H}^{+}
\end{gathered}
$$

${ }^{a}$ School of Landscape Architecture and Art, Hunan Agricultural University, Hunan 41000o, China. E-mail: dexingan@126.com; Tel: +86-13875991861

${ }^{b}$ College of Environmental and Chemical Engineering, Zhaoqing University, Zhaoqing, 526061, China. E-mail: xiechsh@126.com; Tel: +86-13802754169

$$
\mathrm{SO}_{4}{ }^{--}+\mathrm{OH}^{-} \rightarrow \mathrm{SO}_{4}{ }^{2-}+\mathrm{OH}^{\cdot}
$$

However, it is generally known that hydrogen peroxide needs to be added continuously, and the $\mathrm{pH}$ requirements are strict (the optimal pH range is only 2-4) for the traditional Fenton system. ${ }^{14-16}$ As a comparison, PS is added to the system instead of hydrogen peroxide, and PS can exist in a water environment for a longer time. ${ }^{17}$ Generally speaking, the $\mathrm{pH}$ application range is wider in the system of activation of persulfate. Moreover, the reaction between $\mathrm{S}_{2} \mathrm{O}_{8}{ }^{2-}$ and $\mathrm{Fe}^{2+}$ is too rapid to control, which could lead to the result that excess ferrous ions and $\mathrm{SO}_{4}{ }^{-}$in the solution react quickly within a short time. Some of the $\mathrm{SO}_{4}{ }^{-{ }^{-}}$radicals in the system are consumed, which leads to a decrease in the utilization of $\mathrm{SO}_{4}{ }^{-{ }^{-}}$(eqn (4)). ${ }^{18}$ Ferric ions are prone to precipitation under alkaline conditions, resulting in secondary pollution. In recent years, heterogeneous catalysts have attracted the attention of researchers, and can overcome the shortcomings mentioned above. ${ }^{19-21}$ Clays have been used as catalyst carriers because of their high surface area and rich reserves. ${ }^{22} \mathrm{~A}$ large number of studies have been carried out to use modified clay as a photo-Fenton catalyst for the degradation of pollutants. ${ }^{23,24}$ However, iron-pillared clay as a heterogeneous catalyst activated $\mathrm{S}_{2} \mathrm{O}_{8}{ }^{2-}$ for the degradation of organic dyes under visible light irradiation has hardly been explored.

$$
\mathrm{SO}_{4}{ }^{--}+\mathrm{Fe}^{2+} \rightarrow \mathrm{SO}_{4}^{2-}+\mathrm{Fe}^{3+}
$$

Herein, we successfully fabricated $\mathrm{Fe}_{2} \mathrm{O}_{3}$ pillared kaolin photocatalysts, which displayed superior oxygen activation 
ability for the degradation of rhodamine $\mathrm{B}(\mathrm{RhB})$ and antibiotic ciprofloxacin (CIP) in the presence of PS. The optimal reaction conditions of the system were studied, including catalyst dosage, $\mathrm{PS}$ concentration, $\mathrm{RhB}$ concentration, $\mathrm{pH}$ and inorganic anions. The inhibition effects of inorganic anions on the system were also observed. An environmental model application experiment using $\mathrm{Fe}_{2} \mathrm{O}_{3}$ pillared kaolin was carried out. Furthermore, a cycling experiment confirmed that the catalyst has excellent stability. A reaction mechanism for the system was proposed based on the experimental results of free radical capture.

\section{Experimental}

\subsection{Chemicals}

Ferric nitrate $\left(\mathrm{Fe}\left(\mathrm{NO}_{3}\right)_{3} \cdot 9 \mathrm{H}_{2} \mathrm{O}\right)$, sodium chloride $(\mathrm{NaCl})$, sodium carbonate $\left(\mathrm{Na}_{2} \mathrm{CO}_{3}\right)$ hydrochloric acid $(\mathrm{HCl})$, potassium persulfate $\left(\mathrm{K}_{2} \mathrm{O}_{8} \mathrm{~S}_{2}\right)$, sodium hydroxide $(\mathrm{NaOH})$, isopropanol (IPA, $\left.\mathrm{C}_{3} \mathrm{H}_{8} \mathrm{O}\right)$, methanol $\left(\mathrm{MeOH}, \mathrm{CH}_{3} \mathrm{OH}\right)$, ethanol $\left(\mathrm{C}_{2} \mathrm{H}_{6} \mathrm{O}\right), p$-benzoquinone (BQ, $\mathrm{C}_{6} \mathrm{H}_{4} \mathrm{O}_{2}$ ), kaolin $\left(\mathrm{Al}_{2} \mathrm{O}_{3} \cdot 2 \mathrm{SiO}_{2} \cdot 2 \mathrm{H}_{2} \mathrm{O}\right)$, and ciprofloxacin (CIP, $\mathrm{C}_{17} \mathrm{H}_{19} \mathrm{ClFN}_{3} \mathrm{O}_{3}$ ) of analytical grade, were purchased from Sinopharm Chemical Reagent Co. Ltd. Rhodamine $\mathrm{B}\left(\mathrm{RhB}, \mathrm{C}_{28} \mathrm{H}_{31} \mathrm{ClN}_{2} \mathrm{O}_{3}\right)$, methyl orange ( $\mathrm{MO}, \mathrm{C}_{14^{-}}$ $\mathrm{H}_{14} \mathrm{~N}_{3} \mathrm{NaO}_{3} \mathrm{~S}$ ), and methylene blue ( $\mathrm{MB}, \mathrm{C}_{16} \mathrm{H}_{18} \mathrm{~N}_{3} \mathrm{~S} \cdot \mathrm{Cl}$ ) were obtained from the market. In all the experiments, all solutions were prepared with deionized water.

\subsection{Synthesis}

In a typical procedure, first, $8.05 \mathrm{~g}$ of $\mathrm{Fe}\left(\mathrm{NO}_{3}\right)_{3} \cdot 9 \mathrm{H}_{2} \mathrm{O}$ and $1.06 \mathrm{~g}$ of $\mathrm{Na}_{2} \mathrm{CO}_{3}$ respectively were added to $100 \mathrm{~mL}$ of water under stirring, and the solutions were labelled A and B. Solution A was added dropwise to solution B. Secondly, the mixed solution was aged at room temperature for $24 \mathrm{~h}$, and was labelled solution $\mathrm{C}$ (brown). $100 \mathrm{~mL}$ of solution $\mathrm{C}$ was added dropwise to $\mathrm{Na}$ modified kaolin (a mixture of kaolin and $3 \mathrm{wt} \% \mathrm{NaCl}$ ) and stirred continuously at $60{ }^{\circ} \mathrm{C}$ for $2 \mathrm{~h}$, and then allowed to stand at $65{ }^{\circ} \mathrm{C}$ for $12 \mathrm{~h}$. Thirdly, the solid powder was washed with water and ethanol three times each. Fourthly, the obtained dark brown product was dried in an oven at $60^{\circ} \mathrm{C}$ for 6 hours. Finally, the catalyst was further calcined at $400{ }^{\circ} \mathrm{C}$ for 3 hours in air and denoted as $\mathrm{K}-\mathrm{Fe}_{2} \mathrm{O}_{3}$.

\subsection{Characterization}

The phase of the catalyst was determined by X-ray diffraction (XRD, D8-Advance, Bruker, Germany) with a diffraction angle from $5^{\circ}$ to $70^{\circ}$. The morphologies and microstructures of the samples were observed by scanning electron microscopy (SEM, Zeiss Sigma) and high-resolution transmission electron microscopy (HRTEM, FEI Tecnai G2 f20 s-twin $200 \mathrm{kV}$ ). X-ray photoelectron spectroscopy (XPS, K-Alpha model by Thermo Fisher Scientific) analysis was performed, and all binding energies were calibrated with the binding energy of $\mathrm{C} 1 \mathrm{~s}$ as reference. The specific surface areas of the samples were measured with a gas sorption analyzer Autosorb-iQ instrument. Fourier transform infrared (FT-IR) spectroscopy (Shimadzu
FTIR-8400, Japan) was used to detect the change in chemical bonds of the catalyst before and after utilization.

\subsection{Degradation experiments}

The photocatalytic performance of the $\mathrm{K}-\mathrm{Fe}_{2} \mathrm{O}_{3}$ catalyst was evaluated by the degradation of RhB in water, using an LED lamp $(\lambda=420 \mathrm{~nm}, 300 \mathrm{~W})$ as light source. $0.5 \mathrm{~g} \mathrm{~L}^{-1}$ of the $\mathrm{K}$ $\mathrm{Fe}_{2} \mathrm{O}_{3}$ catalyst, $8 \mathrm{mM}$ of $\mathrm{K}_{2} \mathrm{O}_{8} \mathrm{~S}_{2}$ and $10 \mathrm{mg} \mathrm{L}^{-1}$ of $\mathrm{RhB}$ aqueous solution $(100 \mathrm{~mL})$ were added to a $250 \mathrm{~mL}$ glass beaker under stirring at $25{ }^{\circ} \mathrm{C} .5 \mathrm{~mL}$ of the suspension was taken from the tubes at predetermined time intervals and then centrifuged. Lastly, the concentration of RhB was analyzed using a UV-vis spectrophotometer (UV-1240, Shimadzu Corporation, Japan) at the maximum absorption wavelength of $554 \mathrm{~nm}$.

\section{Results and discussion}

\subsection{Characterization and properties of catalysts}

As shown in Fig. 1a, the phase and purity of the as-prepared samples were investigated by XRD analysis. Most of characteristic peaks agreed well with the standard card for kaolin (JCPDS: 25-0021). In addition, the diffraction peaks at $2 \theta=33.1^{\circ}$ and $35.6^{\circ}$ corresponded to the (104) and (110) planes of $\mathrm{Fe}_{2} \mathrm{O}_{3}$ (JCPDS: 33-0664), respectively. This implied that the introduction of $\mathrm{Fe}_{2} \mathrm{O}_{3}$ did not change the main structure of kaolin. Moreover, the morphology of the catalyst can be clearly observed by SEM analysis. Fig. $1 \mathrm{~b}$ and displays the SEM images of kaolin and $\mathrm{K}-\mathrm{Fe}_{2} \mathrm{O}_{3}$. We can see that all the catalyst samples had a layered structure and a lot of amorphous $\mathrm{Fe}_{2} \mathrm{O}_{3}$ could be observed on the surface of the kaolin. ${ }^{25}$ Therefore, the adsorption capacity of the modified catalyst has been greatly improved. ${ }^{26}$ The results from XRD and SEM analyses of the samples suggest that the $\mathrm{K}-\mathrm{Fe}_{2} \mathrm{O}_{3}$ catalyst has been successfully synthesized. Nitrogen adsorption-desorption isotherms of the as-prepared $\mathrm{K}-\mathrm{Fe}_{2} \mathrm{O}_{3}$ are shown in Fig. 1c. The inset of Fig. 1c shows the pore size distribution of the samples. We can see that the range of the main pore size distribution was 5-15 $\mathrm{nm}$. The BET surface areas of the kaolin and $\mathrm{K}-\mathrm{Fe}_{2} \mathrm{O}_{3}$ catalyst were 11.818 and $27.715 \mathrm{~m}^{2} \mathrm{~g}^{-1}$. Remarkably, the surface area substantially increased after pillaring, which was consistent with the result of SEM.

To further verify the chemical constitution of $\mathrm{K}-\mathrm{Fe}_{2} \mathrm{O}_{3}$, the EDX elemental mapping images and the HRTEM image of K$\mathrm{Fe}_{2} \mathrm{O}_{3}$ are shown in Fig. 2 and 3. As we know, there are only three elements in kaolin: $\mathrm{Si}, \mathrm{Al}$ and $\mathrm{O}\left(\mathrm{Al}_{2} \mathrm{O}_{3} \cdot 2 \mathrm{SiO}_{2}\right)$. However, a homogeneous distribution of $\mathrm{Fe}, \mathrm{Si}, \mathrm{Al}$ and $\mathrm{O}$ can be found in the as-prepared samples. Moreover, many clear lattice fringes are displayed in the HRTEM image of $\mathrm{K}-\mathrm{Fe}_{2} \mathrm{O}_{3}$. The widths of these lattice fringe spacings were measured by using the corresponding tools. Lattice fringe spacings of $0.25 \mathrm{~nm}$ correspond to the (110) crystal plane of $\mathrm{Fe}_{2} \mathrm{O}_{3}$, which is consistent with the result from XRD. These results indicate that the $\mathrm{Fe}_{2} \mathrm{O}_{3}$ particles were successfully incorporated into the inside of the kaolin.

XPS analysis was investigated to further study the chemical composition of the catalyst. As presented in Fig. 4a, the XPS survey spectrum showed that $\mathrm{O}, \mathrm{Al}, \mathrm{Si}$, and $\mathrm{Fe}$ elements were 

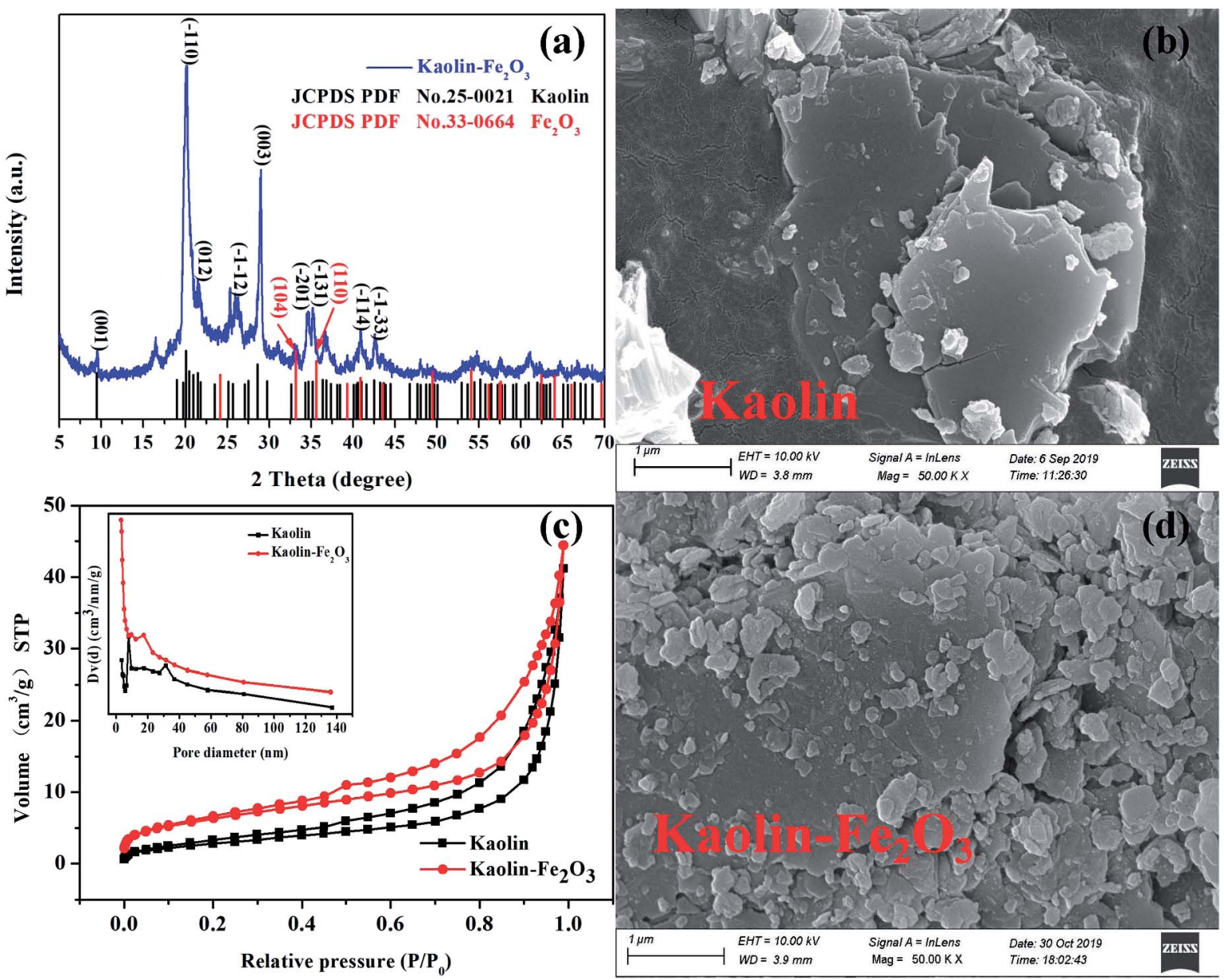

Fig. 1 (a) The XRD pattern of as-prepared $\mathrm{K}-\mathrm{Fe}_{2} \mathrm{O}_{3}$, (c) $\mathrm{N}_{2}$ adsorption-desorption isotherms and the pore size distribution curve (inset) for $\mathrm{K}$ $\mathrm{Fe}_{2} \mathrm{O}_{3}$ and ( $\mathrm{b}$ and d) SEM images of kaolin and $\mathrm{K}-\mathrm{Fe}_{2} \mathrm{O}_{3}$.

present in $\mathrm{K}-\mathrm{Fe}_{2} \mathrm{O}_{3}$ (the $\mathrm{C}$ element came from the carbon source in the instrument). Fig. $4 \mathrm{~b}$ shows the XPS spectra of $\mathrm{Fe} 2 \mathrm{p}$. The peaks appearing at $711 \mathrm{eV}, 714.6,724.6$ and $727.5 \mathrm{eV}$ correspond to $\mathrm{Fe} 2 \mathrm{p}_{3 / 2}$ and $\mathrm{Fe} 2 \mathrm{p}_{1 / 2}$ in Fig. $4 \mathrm{~b}$, and are assignable to $\mathrm{Fe}^{3+}$. The satellite peak at $718.8 \mathrm{eV}$ is characteristic of $\mathrm{Fe}^{3+}$, suggesting that the $\mathrm{Fe}$ in the as-prepared samples is mostly $\mathrm{Fe}^{3+} \cdot{ }^{27}$ Moreover, the XPS spectrum of the Fe 2p peak for pure $\mathrm{Fe}_{2} \mathrm{O}_{3}$ is shown in Fig. 4b, where it is found that the characteristic peaks of $\mathrm{Fe} 2 \mathrm{p}$ agree well with the $\mathrm{K}-\mathrm{Fe}_{2} \mathrm{O}_{3}$ samples. The results of XPS confirmed that $\mathrm{Fe}_{2} \mathrm{O}_{3}$ existed in the as-prepared samples.

\subsection{Degradation of organic pollutants by $\mathrm{K}_{-}-\mathrm{Fe}_{2} \mathrm{O}_{3}$}

3.2.1. Photo-Fenton degradation of RhB. The effects of visible light and PS on the photocatalytic performance of K$\mathrm{Fe}_{2} \mathrm{O}_{3}$ under different comparative conditions were studied. The results of the degradation of $\mathrm{RhB}$ are presented in Fig. 5a. Firstly, in the RhB/visible light system (curve I), there was almost no degradation effect. This shows that the photolysis ability of $\mathrm{RhB}$ is very weak. In the $\mathrm{RhB} / \mathrm{K}-\mathrm{Fe}_{2} \mathrm{O}_{3} /$ darkness system (curve II), the degradation ratio of $\mathrm{RhB}$ was only $8 \%$ within 60 min, indicating that the $\mathrm{K}^{-} \mathrm{Fe}_{2} \mathrm{O}_{3}$ catalyst had a weak adsorption capacity. More obvious discoloration phenomena appeared in the RhB aqueous solution after extra addition of PS (curve VI). Moreover, in the $\mathrm{RhB} / \mathrm{K}-\mathrm{Fe}_{2} \mathrm{O}_{3} / \mathrm{PS} /$ visible light system (curve VII), the degradation ratio of $\mathrm{RhB}$ increased to $99.8 \%$. Next, in the $\mathrm{RhB} / \mathrm{K}-\mathrm{Fe}_{2} \mathrm{O}_{3} /$ visible light system (curve IV), a $42.8 \%$ degradation ratio of RhB was observed. The results of curve VII and curve IV show that the addition of PS was crucial to changing the photocatalytic activity of $\mathrm{K}^{-} \mathrm{Fe}_{2} \mathrm{O}_{3}$. Finally, as shown in curve $\mathrm{V}$, without the $\mathrm{K}-\mathrm{Fe}_{2} \mathrm{O}_{3}$ catalyst, the degradation ratio of $\mathrm{RhB}(54.7 \%)$ was slightly higher than that of curve IV. This was because $\mathrm{S}_{2} \mathrm{O}_{8}{ }^{2-}$ could oxidize some $\mathrm{RhB}$ molecules into degraded products under visible light irradiation. Fig. 5b shows that the degradation curves of the different reaction systems followed a first-order kinetics model, and the reaction kinetic constant $(k)$ in curve VII was more than 3.5 times higher than that of the other all curves. The results of the controlled experiments showed that the catalyst, PS and visible light all played an important role in the above system.

As shown in Fig. $5 \mathrm{c}$, there was a significant decrease in the UV-vis absorption peak at $554 \mathrm{~nm}$ within $5 \mathrm{~min}$ after turning on the light. This result was in good agreement with degradation activity curve VII. Interestingly, the maximum absorption wavelength of RhB shifted from 554 to $542 \mathrm{~nm}$. Meanwhile, the 

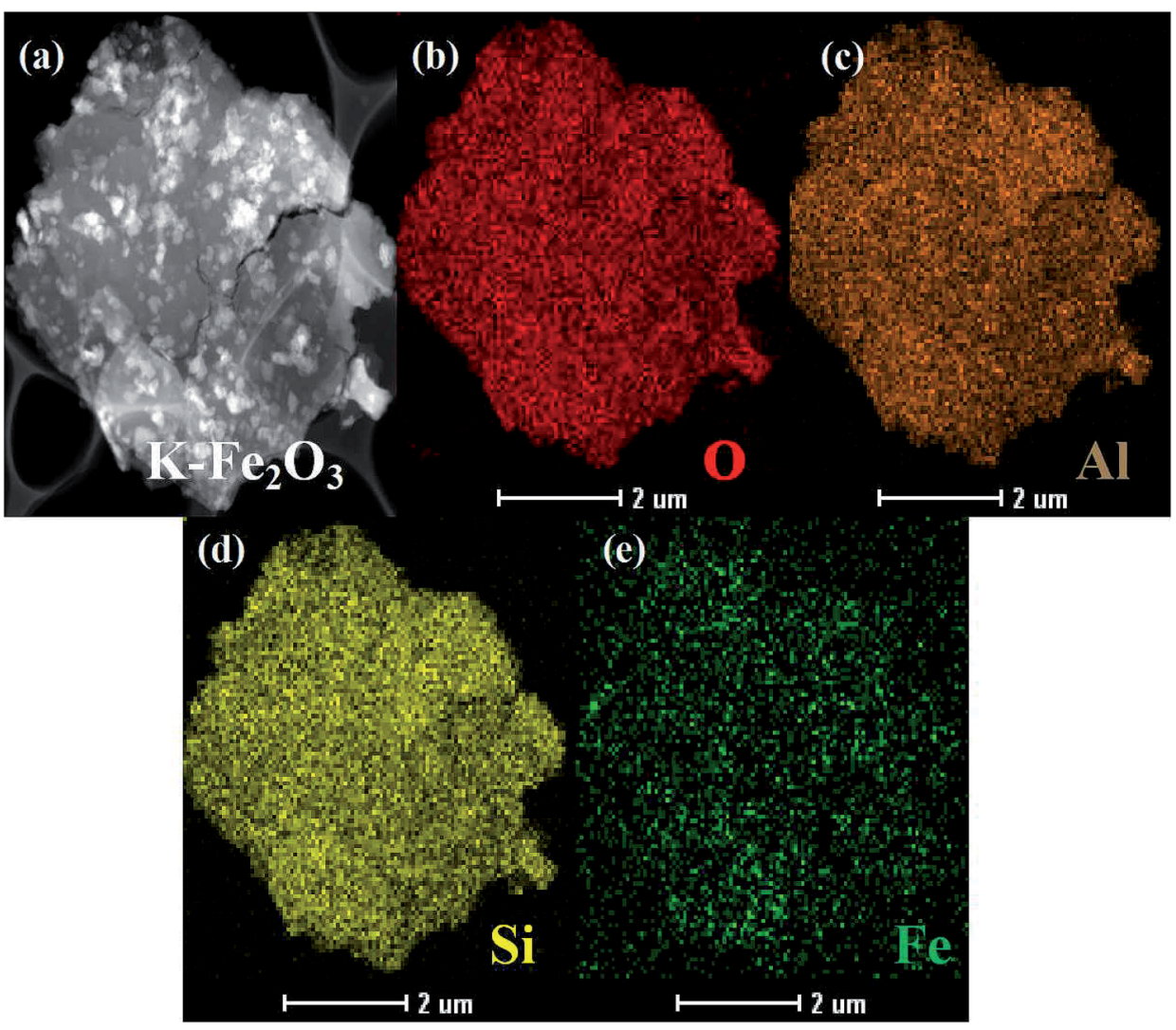

(e)

Fig. 2 (a-e) EDX elemental mapping images of $\mathrm{K}-\mathrm{Fe}_{2} \mathrm{O}_{3}$.

absorption wavelengths at 260, 302, and $352 \mathrm{~nm}$ disappeared after the reaction. This might be because the dye molecule went through $\mathrm{N}$-deethylation, ${ }^{\mathbf{2 8 , 2 9}}$ indicating that the catalyst has successfully destroyed the structure of the RhB molecules. In order to further confirm the photocatalytic performance of the $\mathrm{K}-\mathrm{Fe}_{2} \mathrm{O}_{3}$ catalyst, we measured the change in chemical oxygen demand (COD) value in aqueous solution during the degradation reaction, and the result is displayed in Fig. $5 \mathrm{~d}$. The value of COD in the solution dropped from $69.8 \mathrm{mg} \mathrm{L}^{-1}$ to $8.2 \mathrm{mg} \mathrm{L}^{-1}$ under optimal reaction conditions, and the degradation ratio and COD removal ratio for $\mathrm{RhB}$ were $99.8 \%$ and $88.3 \%$, respectively, exhibiting the excellent mineralization capacity of $\mathrm{Fe}_{2} \mathrm{O}_{3}$.

3.2.2. Effect of PS concentration. The influence of PS concentration of the initial solution on the degradation of $\mathrm{RhB}$ in the $\mathrm{K}-\mathrm{Fe}_{2} \mathrm{O}_{3} / \mathrm{PS} /$ visible light system is shown in Fig. $6 \mathrm{~b}$. It can obviously be observed from the figure that when the concentration of PS increased from $1 \mathrm{mmol} \mathrm{L}^{-1}$ to $4 \mathrm{mmol} \mathrm{L}^{-1}$, the degradation ratio of $\mathrm{RhB}$ increased from $70.3 \%$ to $92.4 \%$ within $60 \mathrm{~min}$. But the initial PS concentration had a saturation value ( $\geq 8 \mathrm{mM}$ ), and although the concentration of PS continued to increase, the photocatalytic activity of $\mathrm{K}-\mathrm{Fe}_{2} \mathrm{O}_{3}$ remained almost unchanged. In order to ensure a good degradation efficiency and save materials, in this study, the optimal initial PS concentration was $1.0 \mathrm{mM}$.

3.2.3. Effect of catalyst dosage. The influence of the dosage of $\mathrm{K}-\mathrm{Fe}_{2} \mathrm{O}_{3}$ catalyst on the degradation of $\mathrm{RhB}$ in the $\mathrm{K}-\mathrm{Fe}_{2} \mathrm{O}_{3} / \mathrm{PS}$ / visible light system is shown in Fig. 6a. When the dosages of the catalyst were $0.1 \mathrm{~g} \mathrm{~L}^{-1}, 0.25 \mathrm{~g} \mathrm{~L}^{-1}, 0.5 \mathrm{~g} \mathrm{~L}^{-1}$ or $1.0 \mathrm{~g} \mathrm{~L}^{-1}$, the degradation ratios of $\mathrm{RhB}$ were $83.2 \%, 88.8 \%$, 99.5\% and $100 \%$ after $60 \mathrm{~min}$. An increase in the catalyst may increase the number of active sites in the reaction system by increasing the contact area between the catalyst and contaminant molecules. This phenomenon was observed at the beginning of the degradation reaction. However, when the catalyst dosage exceeded a maximum value $\left(0.5 \mathrm{~g} \mathrm{~L}^{-1}\right)$, the degradation effect of RhB had not changed much, because the excessive catalyst blocked the visible light irradiation. ${ }^{30}$ Additionally, for recycling, the dosage of catalyst should not be too small. In this study, the optimal catalyst dosage was $0.5 \mathrm{~g} \mathrm{~L}^{-1}$.

3.2.4. Effect of $\mathbf{R h B}$ concentration. As we know, for the same oxidation system, the degradation effect may vary greatly with different concentrations of pollutant. ${ }^{31}$ The influence of the concentration of $\mathrm{RhB}$ in the initial solution on the degradation of $\mathrm{RhB}$ in the $\mathrm{K}-\mathrm{Fe}_{2} \mathrm{O}_{3} / \mathrm{PS} /$ visible light system is shown in Fig. 6c. We found that even if the concentration of the dye (10.0 $\left.\mathrm{mg} \mathrm{L}^{-1}\right)$ was increased by 5 times $\left(50.0 \mathrm{mg} \mathrm{L}^{-1}\right)$, the degradation ratio of $\mathrm{RhB}$ by the $\mathrm{K}-\mathrm{Fe}_{2} \mathrm{O}_{3} / \mathrm{PS} /$ visible light system was still over $98 \%$. In contrast, other studies have reported different experimental phenomena. ${ }^{32}$ With an increase in the concentration of RhB, the above system had a negative effect on the degradation of $\mathrm{RhB}$. The results of this experiment demonstrate the strong oxidation performance of the $\mathrm{K}-\mathrm{Fe}_{2} \mathrm{O}_{3}$ catalyst and the system could indiscriminately degrade 


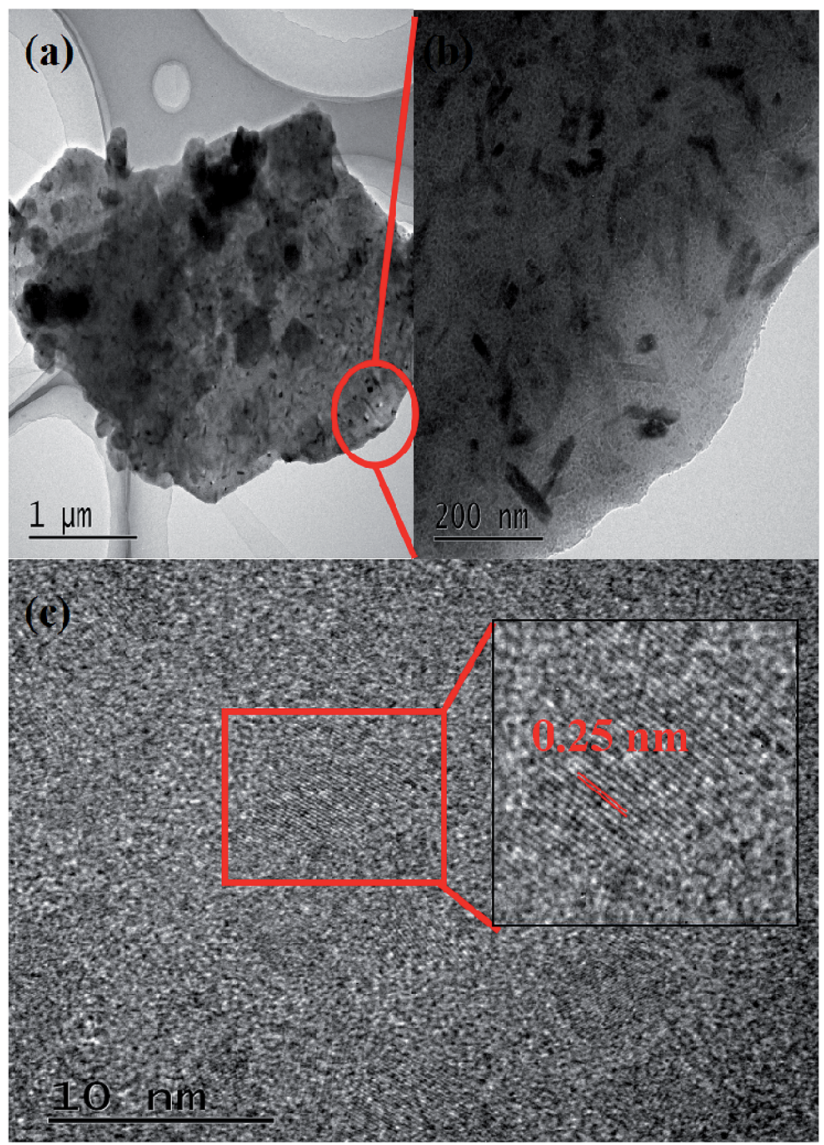

Fig. 3 ( $a$ and b) TEM images and (c) a HRTEM image of $\mathrm{K}-\mathrm{Fe}_{2} \mathrm{O}_{3}$

different concentrations of RhB. This also showed that the synthesized $\mathrm{K}-\mathrm{Fe}_{2} \mathrm{O}_{3}$ catalyst has a good environmental application performance under the activation of PS.

3.2.5. Effect of pH. Generally, the oxidation system did not exhibit an excellent degradation effect in alkaline wastewater. In order to explore the influence of initial solution $\mathrm{pH}$ on the degradation of $\mathrm{RhB}$ in the $\mathrm{K}-\mathrm{Fe}_{2} \mathrm{O}_{3} / \mathrm{PS} /$ visible light system, as shown in Fig. 6d, we adjusted the initial $\mathrm{pH}$ of $\mathrm{RhB}$ solution to 2.9-10.0 with $\mathrm{NaOH} / \mathrm{HCl}$. Interestingly, even when the initial $\mathrm{pH}$ was 10.0 , the degradation ratio of $\mathrm{RhB}$ still reached more than $95 \%$ within $60 \mathrm{~min}$. This might be attributed to the electronegativity and strong adsorption of clay minerals. ${ }^{33}$ Without adjusting the initial solution $\mathrm{pH}$, the degradation ratio of $\mathrm{RhB}$ was $98.8 \%(\mathrm{pH}=6.3)$. At $\mathrm{pH}=2.9$, the $\mathrm{K}-\mathrm{Fe}_{2} \mathrm{O}_{3} / \mathrm{PS} /$ visible light system showed the best degradation efficiency (100\%). This was because the $\mathrm{Fe}^{2+} / \mathrm{PS}$ system could produce active free radicals under acidic, neutral or even alkaline conditions (eqn (2) and (3)). The above results showed that this system could overcome the shortcoming of $\mathrm{pH}$ value in dye wastewater treatment. ${ }^{34,35}$

3.2.6. Effect of inorganic anions. In practice, organic wastewater contains a variety of complex components, which can scavenge active radicals and reduce the degradation ratio of pollutants. ${ }^{36}$ Typically, the effects of different inorganic anions $\left(\mathrm{Cl}^{-}, \mathrm{SO}_{4}{ }^{2-}, \mathrm{CO}_{3}{ }^{2-}, \mathrm{NO}_{3}{ }^{-}\right)$on the degradation of $\mathrm{RhB}$ in the $\mathrm{K}-$ $\mathrm{Fe}_{2} \mathrm{O}_{3} / \mathrm{PS} /$ visible light system were studied. From Fig. 7a, we can see that 4 kinds of inorganic ions have certain negative effects on the degradation reaction. Besides, it is shown that the inhibition of $\mathrm{RhB}$ degradation by the $\mathrm{K}-\mathrm{Fe}_{2} \mathrm{O}_{3} / \mathrm{PS} /$ visible light system followed the trend: $\mathrm{SO}_{4}{ }^{2-}<\mathrm{NO}_{3}{ }^{-}<\mathrm{Cl}^{-}<\mathrm{CO}_{3}{ }^{2-}$. The main reason was that inorganic anions react with free radicals $\left(\mathrm{SO}_{4}{ }^{-\cdot}\right.$ and $\left.\mathrm{OH}^{-}\right)$to form other products with weak oxidizing properties $\left(\mathrm{CO}_{3}{ }^{-}, \mathrm{Cl}^{\bullet}, \mathrm{Cl}_{2}{ }^{-\cdot}, \mathrm{NO}_{3}{ }^{\circ}\right)$, as shown in eqn (5)-(9)..$^{37,38}$ $\mathrm{SO}_{4}{ }^{2-}$ and $\mathrm{NO}_{3}{ }^{2-}$ did not cause significant inhibition of $\mathrm{RhB}$ degradation, which might be because $\mathrm{SO}_{4}{ }^{2-}$ did not react with $\mathrm{SO}_{4}{ }^{--}$radicals and the reaction rate constant of eqn (9) was very low..$^{39}$ In order to further study the influence of inorganic ions on the degradation performance for the persulfate system, the $\mathrm{pH}$ value of the solution after adding different inorganic ions was measured. We can see that the $\mathrm{pH}$ value of the other systems was almost unchanged, except for the $\mathrm{CO}_{3}{ }^{2-}$ ion $(\mathrm{pH}=$ 9.4). Additionally, degradation experiments were carried out under only PS and visible light irradiation, and the results are shown in Fig. 7b. The degradation ratio of $\mathrm{RhB}$ in the system
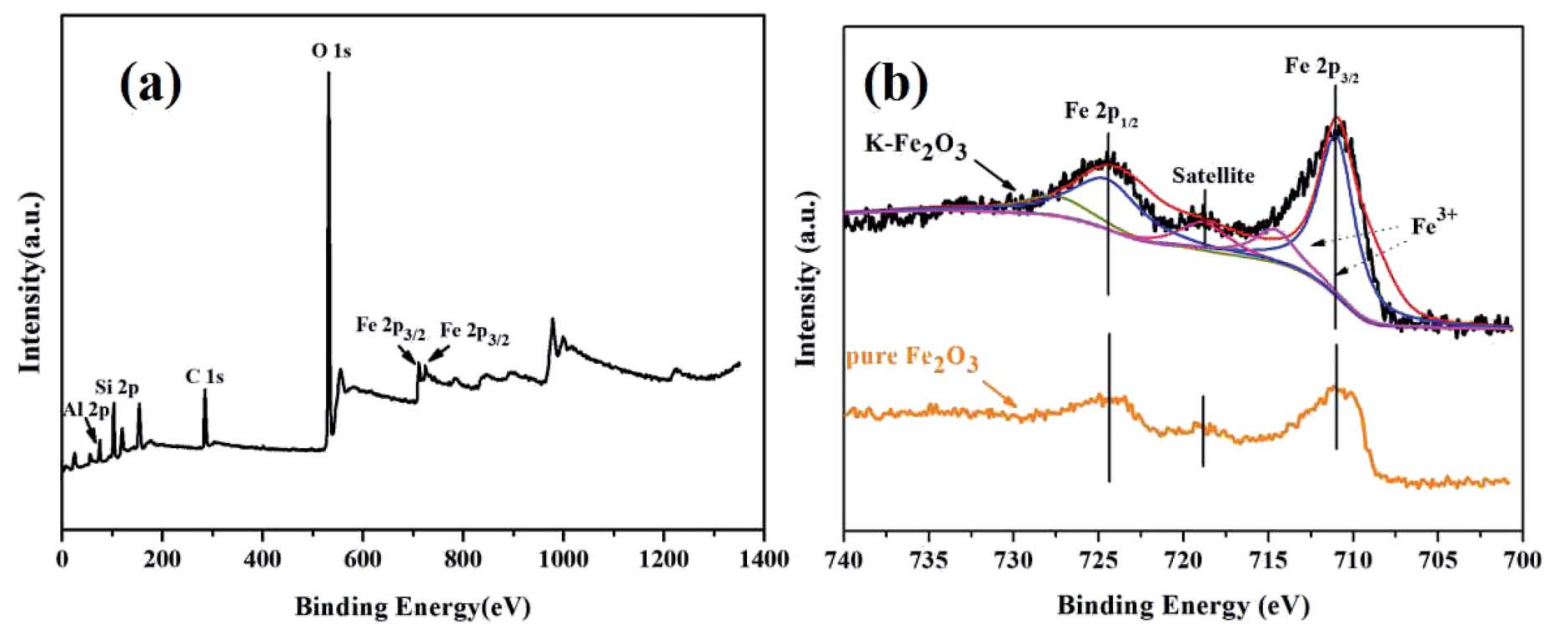

Fig. 4 XPS spectra: (a) survey spectrum of $\mathrm{K}-\mathrm{Fe}_{2} \mathrm{O}_{3}$ and (b) $\mathrm{Fe} 2 \mathrm{p}$ spectra of $\mathrm{K}-\mathrm{Fe}_{2} \mathrm{O}_{3}$ and pure $\mathrm{Fe}_{2} \mathrm{O}_{3}$. 

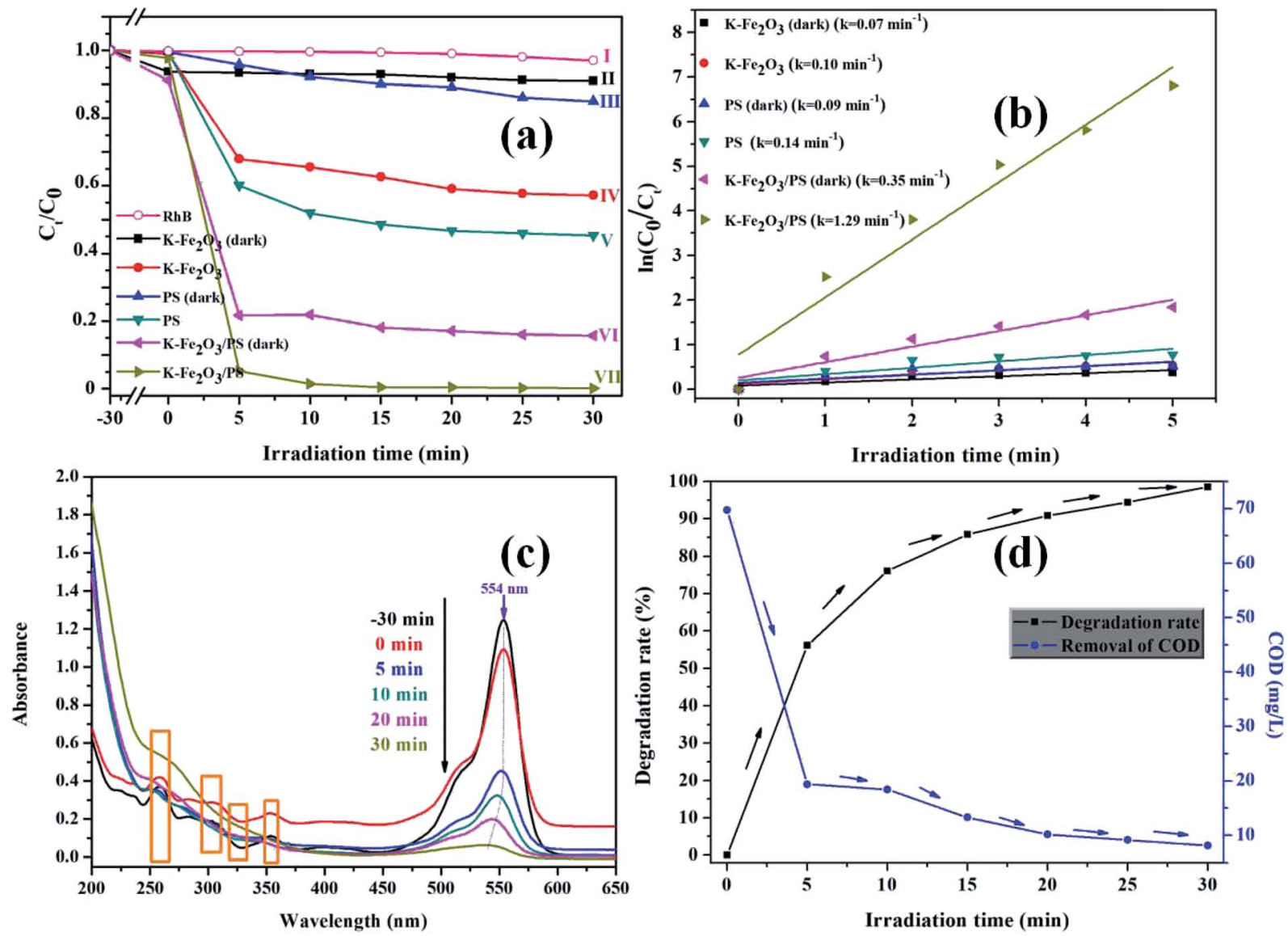

Fig. 5 (a) Photocatalytic degradation activity curves for RhB under different conditions: (I) RhB/visible light; (II) $\mathrm{RhB} / \mathrm{K}-\mathrm{Fe} \mathrm{O}_{3} /$ darkness; (III) RhB/ PS/darkness; (IV) RhB/K- $\mathrm{Fe}_{2} \mathrm{O}_{3} /$ visible light; (V) RhB/PS/visible light; (VI) RhB/K- $\mathrm{Fe}_{2} \mathrm{O}_{3} / \mathrm{PS} /$ darkness, (VII) RhB/K-Fe $\mathrm{O}_{3} / \mathrm{PS} /$ visible light, (b) kinetic curves of $\mathrm{RhB}$ degradation under the above experimental conditions, (c) time-dependent UV-visible absorption spectra of RhB solution over $\mathrm{K}$ $\mathrm{Fe}_{2} \mathrm{O}_{3}$, and (d) the degradation ratio of $\mathrm{RhB}$ and the removal ratio of $\mathrm{COD}$ in the $\mathrm{K}-\mathrm{Fe}_{2} \mathrm{O}_{3} / \mathrm{PS} /$ visible system. Initial conditions: $\mathrm{C}_{\mathrm{RhB}}=10.0 \mathrm{mg} \mathrm{L}^{-1}$, $W_{\text {catalyst }}=50 \mathrm{mg}, C_{\mathrm{PS}}=8 \mathrm{mM}, \mathrm{pH}=$ natural.

without any ions was the highest and the degradation trend of the PS/visible light system is consistent with that of the $\mathrm{K}-\mathrm{Fe}_{2} \mathrm{O}_{3} /$ $\mathrm{PS} /$ visible light system, which further illustrated that $\mathrm{SO}_{4}{ }^{-}$. could react with inorganic ions. This result of this experiment can help environmental practitioners optimize organic pollutant removal efficiency by removing some of the anions.

$$
\begin{gathered}
\mathrm{SO}_{4}{ }^{--}+\mathrm{CO}_{3}{ }^{2-} \rightarrow \mathrm{SO}_{4}{ }^{2-}+\mathrm{CO}_{3}{ }^{-\cdot} \quad k=6.1 \times 10^{6} \mathrm{M}^{-1} \mathrm{~S}^{-1}(5) \\
\mathrm{OH}^{\cdot}+\mathrm{CO}_{3}{ }^{2-} \rightarrow \mathrm{OH}^{-}+\mathrm{CO}_{3}{ }^{-\cdot} \quad k=3.9 \times 10^{8} \mathrm{M}^{-1} \mathrm{~S}^{-1} \\
\mathrm{SO}_{4}{ }^{--}+\mathrm{Cl}^{-} \rightarrow \mathrm{SO}_{4}{ }^{2-}+\mathrm{Cl}^{\cdot} \quad k=3.1 \times 10^{8} \mathrm{M}^{-1} \mathrm{~S}^{-1} \\
\mathrm{Cl}^{\cdot}+\mathrm{Cl}^{-} \rightarrow \mathrm{Cl}_{2}{ }^{-} \quad k=8.0 \times 10^{9} \mathrm{M}^{-1} \mathrm{~S}^{-1} \\
\mathrm{SO}_{4}{ }^{--}+\mathrm{NO}_{3}{ }^{-} \rightarrow \mathrm{SO}_{4}{ }^{2-}+\mathrm{NO}_{3}{ }^{\cdot} \quad k=2.0 \times 10^{2} \mathrm{M}^{-1} \mathrm{~S}^{-1}
\end{gathered}
$$

\subsection{Environmental application of kaolin- $-\mathrm{Fe}_{2} \mathrm{O}_{3}$}

Based on the above results, we found that the $\mathrm{K}-\mathrm{Fe}_{2} \mathrm{O}_{3} / \mathrm{PS} /$ visible light system exhibited an excellent performance in degrading
$\mathrm{RhB}$ in aqueous solution. At the same time, we wondered whether the system could degrade other organic pollutants in the solution. The abuse of antibiotics has led to the increasingly serious pollution of the natural environment by antibiotics. ${ }^{40} \mathrm{In}$ this study, the degradation of a colorless antibiotic ciprofloxacin (CIP) was carried out. Fig. 8a shows the UV-visible absorption spectra changes of CIP solution (maximum absorption wavelength $=270 \mathrm{~nm}$ ) over $\mathrm{K}-\mathrm{Fe}_{2} \mathrm{O}_{3}$, indicating that the degradation ratio of CIP reached $63 \%$ under optimal experimental conditions within $30 \mathrm{~min}$. In addition, we carried out large-scale treatment experiments for dye wastewater (location: $112.51^{\circ}$ East, $23.11^{\circ}$ North, experimental time: Sept. 12, 9:30 AM to 12:00 AM, 12:30 PM to 15:30 PM). As shown in Fig. $8 \mathrm{~b}$, an obvious decolorization was observed in $20 \mathrm{~L}$ of $\mathrm{RhB}$ dye wastewater after $150 \mathrm{~min}$. Furthermore, a kind of wastewater with a complex composition, including three common azo dyes Rhodamine $\mathrm{B}$ (RhB), methyl orange (MO) and methylene blue (MB) was treated under the same conditions. $\mathrm{K}^{-} \mathrm{Fe}_{2} \mathrm{O}_{3}$ still exhibited high photocatalytic performance for a mixed solution. These phenomena suggested that the $\mathrm{K}-\mathrm{Fe}_{2} \mathrm{O}_{3} / \mathrm{PS} /$ visible light system had general applicability for the degradation of organic pollutants. 

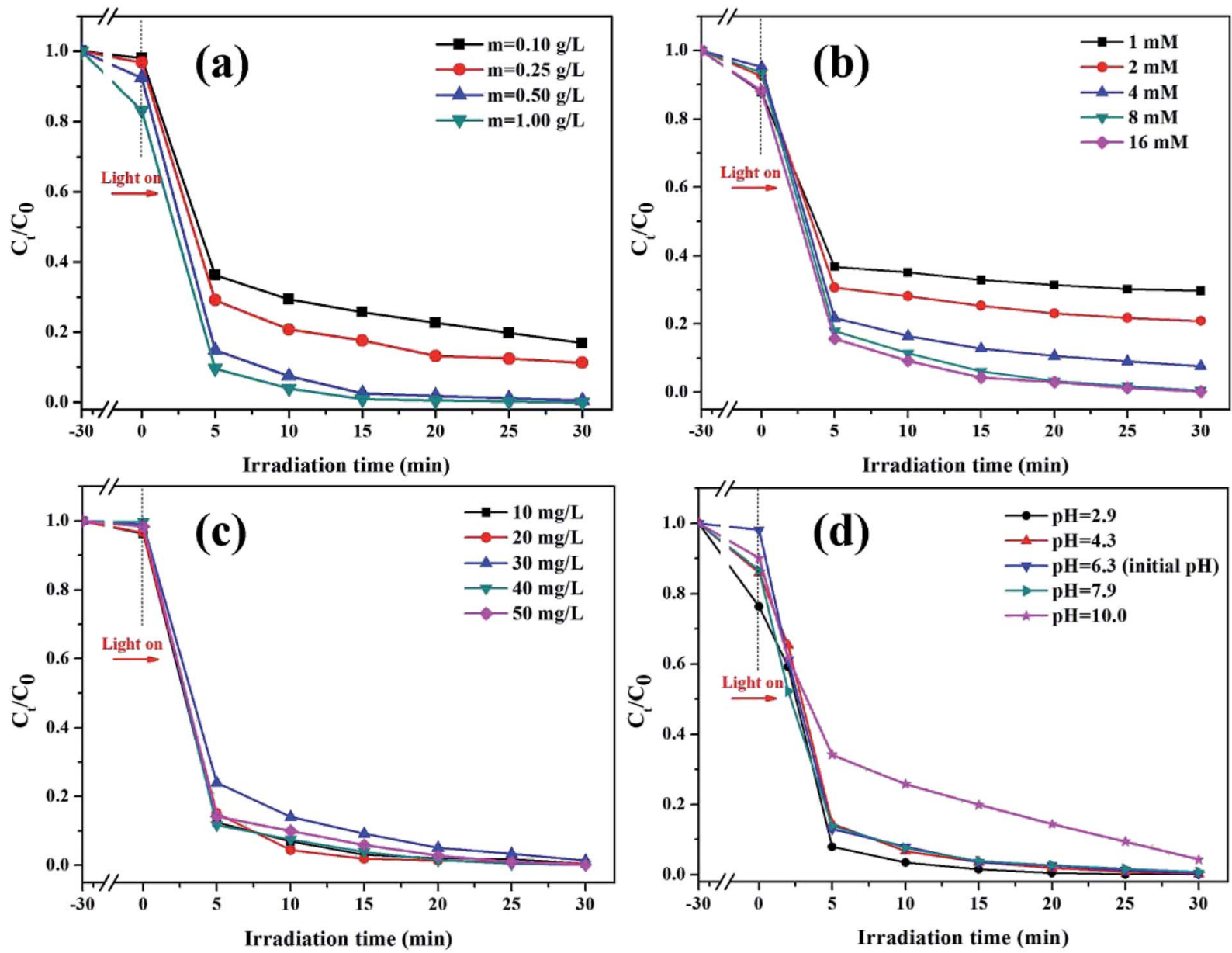

Fig. 6 (a) The effect of catalyst dosage ([PS] $=8 \mathrm{mM}, \mathrm{pH}=6.3,[\mathrm{RhB}]=100 \mathrm{~mL}, 10 \mathrm{mg} \mathrm{L}^{-1}$ ), (b) the effect of PS concentration ([K-Fe $\left.\mathrm{O}_{3}\right]=0.5 \mathrm{~g}$ $\mathrm{L}^{-1}, \mathrm{pH}=6.3,[\mathrm{RhB}]=100 \mathrm{~mL}, 10 \mathrm{mg} \mathrm{L}^{-1}$ ), (c) the effect of RhB concentration ([K-Fe $\left.\mathrm{O}_{3}\right]=0.5 \mathrm{~g} \mathrm{~L}^{-1}$, [PS] $=8 \mathrm{mM}, \mathrm{pH}=6.3$ ), and (d) the effect of the initial $\mathrm{pH}$ on the degradation of $\mathrm{RhB}$ in the $\mathrm{K}-\mathrm{Fe}_{2} \mathrm{O}_{3} / \mathrm{PS} /$ visible light system $\left(\left[\mathrm{K}_{-}-\mathrm{Fe}_{2} \mathrm{O}_{3}\right]=0.5 \mathrm{~g} \mathrm{~L}^{-1},[\mathrm{PS}]=8 \mathrm{mM},[\mathrm{RhB}]=100 \mathrm{~mL}, 10 \mathrm{mg} \mathrm{L}{ }^{-1}\right.$ ).

\subsection{Stability of $\mathrm{K}^{-\mathrm{Fe}_{2}} \mathrm{O}_{3}$}

We explored the stability of the $\mathrm{K}-\mathrm{Fe}_{2} \mathrm{O}_{3}$ through cycling degradation experiments. As shown in Fig. 9a, the degradation ratios of RhB were $99 \%$ on the first run and $96 \%$ on the sixth run, which showed that the $\mathrm{K}-\mathrm{Fe}_{2} \mathrm{O}_{3}$ catalyst was stable during the degradation process. The slight change in the degradation
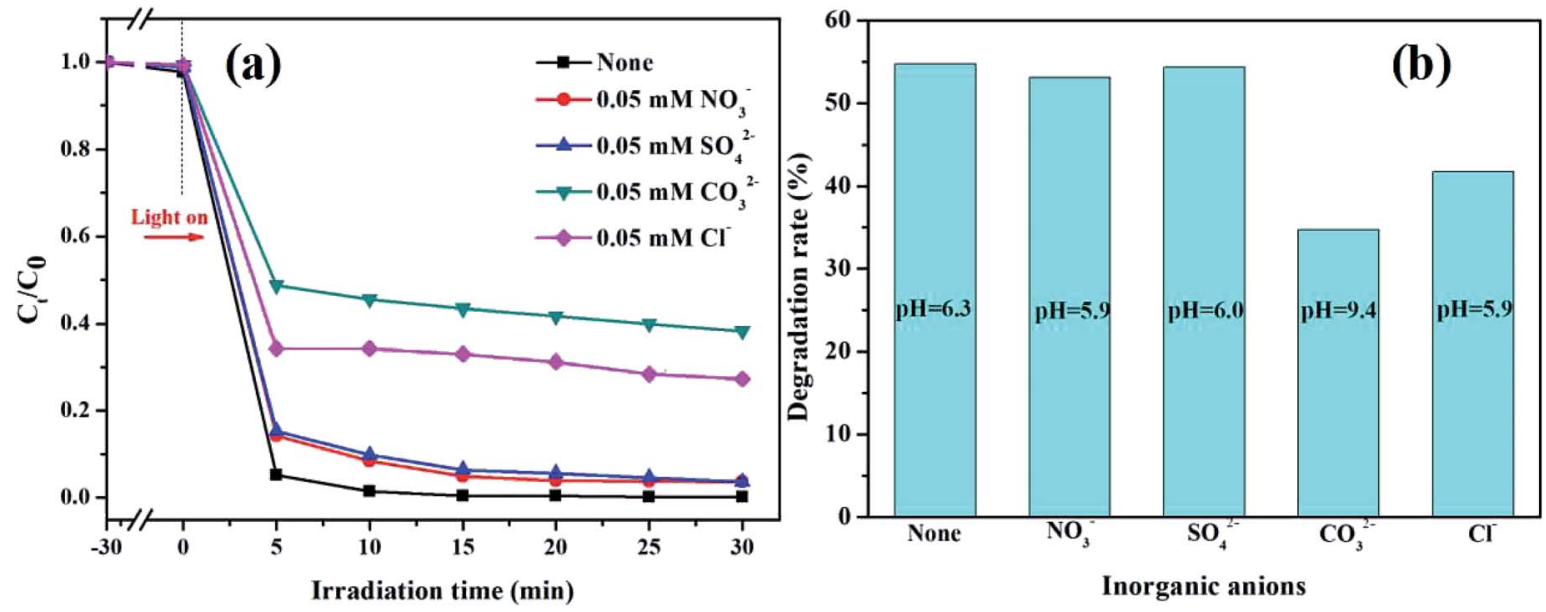

Fig. 7 (a) The effects of different inorganic anions on the degradation of $\mathrm{RhB}$ in the $\mathrm{K}-\mathrm{Fe}_{2} \mathrm{O}_{3} / \mathrm{PS} /$ visible light system $\left(\left[\mathrm{K}-\mathrm{Fe}_{2} \mathrm{O}_{3}\right]=0.5 \mathrm{~g} \mathrm{~L}-1\right.$, $[\mathrm{PS}]=$ $8 \mathrm{mM}, \mathrm{pH}=6.3,[\mathrm{RhB}]=100 \mathrm{~mL}, 10 \mathrm{mg} \mathrm{L}^{-1}$ ), and (b) the effects of different inorganic anions on the degradation of RhB in the PS/visible light system ([PS] $\left.=8 \mathrm{mM},[\mathrm{RhB}]=100 \mathrm{~mL}, 10 \mathrm{mg} \mathrm{L}^{-1}\right)$. 

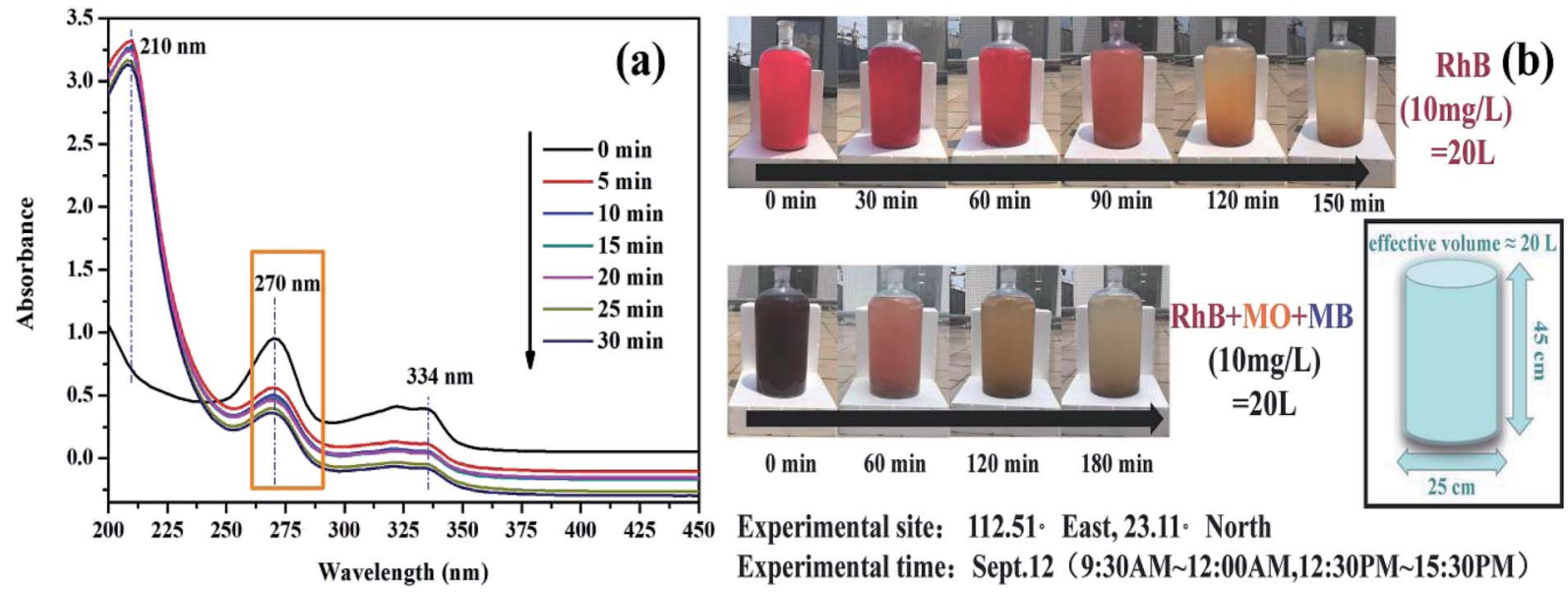

Fig. 8 (a) Time-dependent UV-visible absorption spectra of CIP solution over $\mathrm{K}-\mathrm{Fe}_{2} \mathrm{O}_{3}$, and (b) a large-scale photodegradation system under natural sunlight irradiation with $\mathrm{K}-\mathrm{Fe}_{2} \mathrm{O}_{3}$ catalyst ([K- $\left.\mathrm{Fe}_{2} \mathrm{O}_{3}\right]=0.5 \mathrm{~g} \mathrm{~L}^{-1},[\mathrm{PS}]=8 \mathrm{mM},[\mathrm{CIP}]=100 \mathrm{~mL}, 10 \mathrm{mg} \mathrm{L}^{-1}, \mathrm{pH}=\mathrm{natural}$ ).

ratio of RhB may be due to the loss of catalyst in the recovery process. ${ }^{41}$ Additionally, in order to study the phase change of the catalyst during the degradation reaction process, the FT-IR patterns of fresh $\mathrm{K}-\mathrm{Fe}_{2} \mathrm{O}_{3}$ and used $\mathrm{K}-\mathrm{Fe}_{2} \mathrm{O}_{3}$ are displayed in Fig. 9b. No marked shift in the main characteristic bands at 1057, 582, and $482 \mathrm{~cm}^{-1}$ was observed. Besides, the
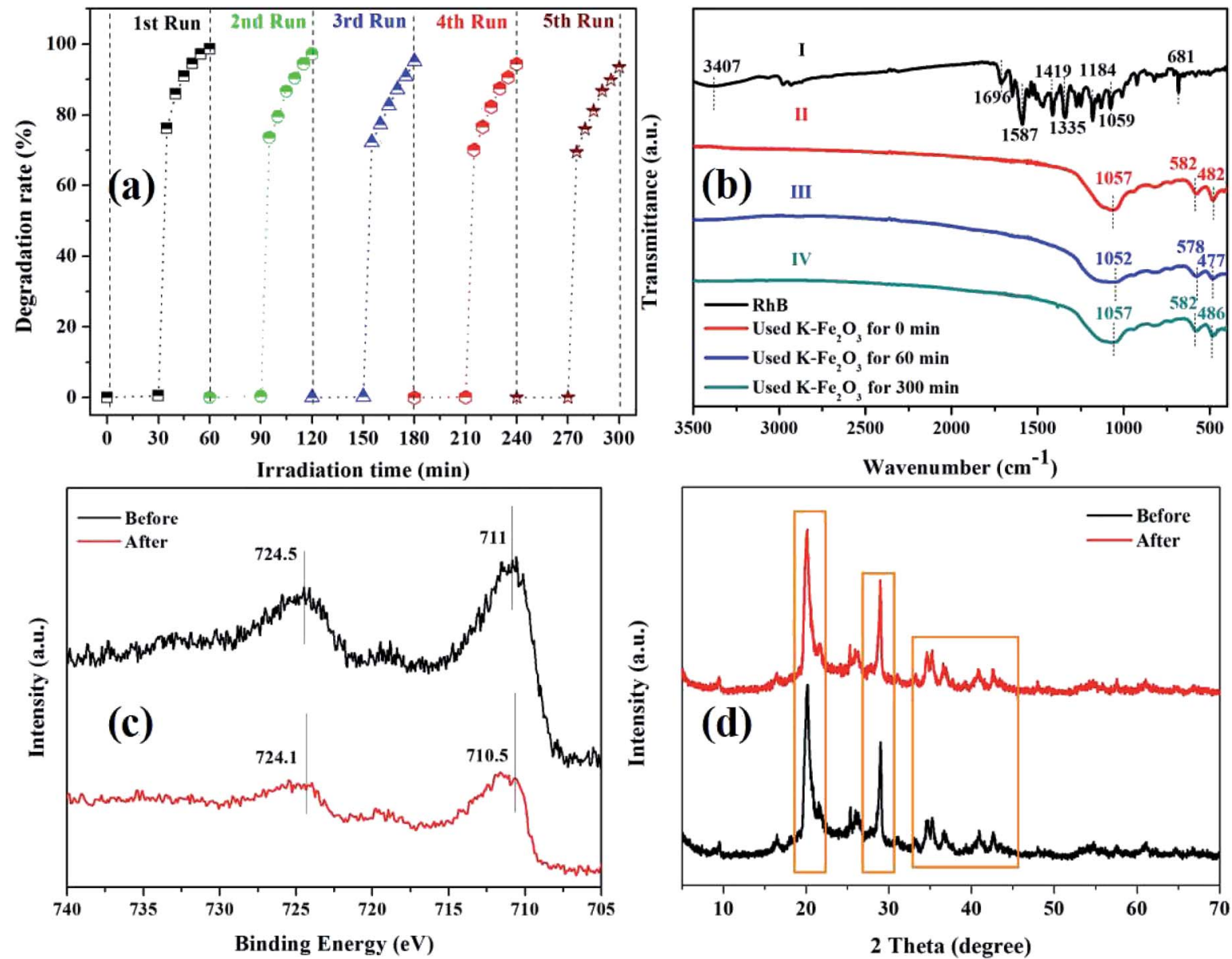

Fig. 9 (a) The recycling performance of the $\mathrm{K}-\mathrm{Fe}_{2} \mathrm{O}_{3}$ catalyst for the degradation of $\mathrm{RhB}$ in aqueous solution, (b) the FT-IR patterns of pure RhB powder and the catalyst after use for $0 \mathrm{~min}, 60 \mathrm{~min}$, and $300 \mathrm{~min}$, (c) the XPS pattern of the catalyst after use for $0 \mathrm{~min}$ and $300 \mathrm{~min}$, and (d) the XRD pattern of the catalyst after use for $0 \mathrm{~min}$ and $300 \mathrm{~min}$. 


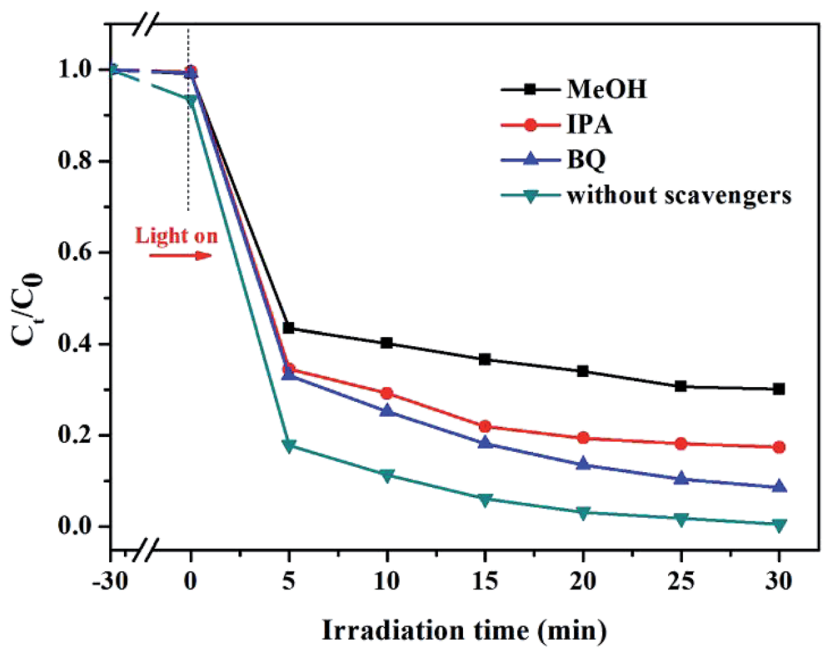

Fig. 10 Photocatalytic activities of the $\mathrm{K}-\mathrm{Fe}_{2} \mathrm{O}_{3}$ catalyst for the degradation of $\mathrm{RhB}$ with different scavengers ( $[\mathrm{RhB}]=10 \mathrm{mg} \mathrm{L}^{-1}, \mathrm{pH}=$ initial value, $\left[\mathrm{K}-\mathrm{Fe}_{2} \mathrm{O}_{3}\right]=0.5 \mathrm{~g} \mathrm{~L}^{-1}$, [PS] $=8 \mathrm{mM}$ ).

characteristic bands of pure $\mathrm{RhB}\left(3407 \mathrm{~cm}^{-1}\right)$ were not found in the spectra of the used $\mathrm{K}-\mathrm{Fe}_{2} \mathrm{O}_{3}$ catalyst, indicating that the dyes were indeed degraded rather than adsorbed. ${ }^{42}$ Moreover, the XPS and XRD patterns of the $\mathrm{K}-\mathrm{Fe}_{2} \mathrm{O}_{3}$ catalyst after using for 0 min and 300 min are displayed in Fig. $9 \mathrm{c}$ and d. The Fe $2 \mathrm{p}$ peak of the used catalyst shifted slightly toward the low binding energy direction, indicating that part of the Fe species on the surface of the $\mathrm{K}-\mathrm{Fe}_{2} \mathrm{O}_{3}$ catalyst was converted to $\mathrm{Fe}(\mathrm{II})$ during the degradation reaction. This further proved that the Fe species on the $\mathrm{K}-\mathrm{Fe}_{2} \mathrm{O}_{3}$ surface are the main active sites for the $\mathrm{K}-\mathrm{Fe}_{2} \mathrm{O}_{3} / \mathrm{PS} /$ visible light system. ${ }^{43}$ As shown in Fig. 9d, the main peaks of the XRD pattern of the catalyst did not shift after use. The above results confirmed that the $\mathrm{K}-\mathrm{Fe}_{2} \mathrm{O}_{3}$ catalyst has excellent stability.

\subsection{Reaction mechanism}

As can be seen in Fig. 10, without using any free radical scavenger, a $99.8 \%$ degradation ratio was reached in the control group. When IPA $(\cdot \mathrm{OH}$ radical scavenger $), \mathrm{BQ}\left(\mathrm{O}_{2}{ }^{\cdot-}\right.$ radical scavenger) and $\mathrm{MeOH}\left(\mathrm{SO}_{4}{ }^{-}\right.$radical scavenger) were added into the reaction solution during the $\mathrm{RhB}$ degradation, the degradation ratios of $\mathrm{RhB}$ dropped to $69.9 \%, 82.6 \%$ and $92.4 \%$ within $60 \mathrm{~min}$, respectively. On the one hand, the addition of $\mathrm{MeOH}$ greatly inhibited the degradation reaction, and this also showed that $\mathrm{SO}_{4}{ }^{-{ }^{-}}$was the major active species in the $\mathrm{K}-\mathrm{Fe}_{2} \mathrm{O}_{3} / \mathrm{PS} /$ visible light system. On the other hand, the $\cdot \mathrm{OH}$ radical also made a certain contribution to degrading RhB in the solution. Similar phenomena have been reported by other researchers, such as Guo et al. ${ }^{44}$ and $\mathrm{Hu}$ et al. ${ }^{45}$ The above results indicated that the $\mathrm{K}^{-} \mathrm{Fe}_{2} \mathrm{O}_{3} / \mathrm{PS} / \mathrm{visible}$ light Fenton-like system can produce two active radicals, $\mathrm{SO}_{4}{ }^{\cdot-}$ and $\cdot \mathrm{OH}$, and the organic pollutants were efficiently removed through the common oxidation of the two radicals.

A possible degradation mechanism of organic pollutants in the $\mathrm{K}-\mathrm{Fe}_{2} \mathrm{O}_{3} / \mathrm{PS} /$ visible light system is proposed. As displayed in

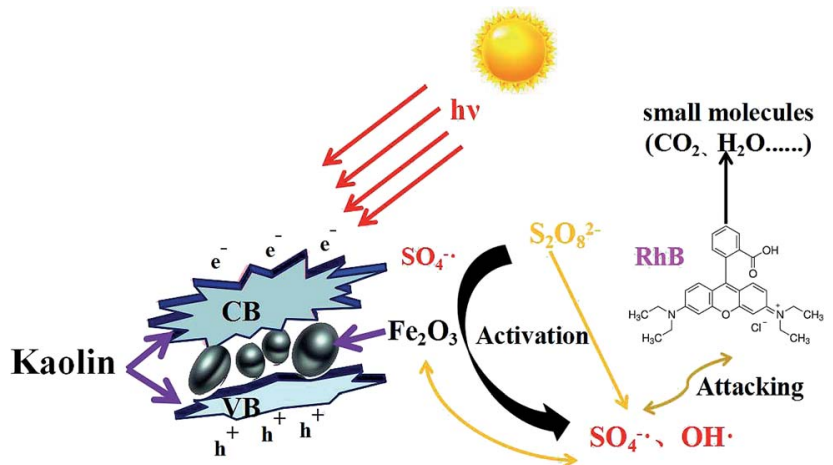

Fig. 11 The proposed mechanism for the degradation of organic pollutants in the $\mathrm{Fe}_{2} \mathrm{O}_{3}$-pillared kaolin/PS/visible light system.

Fig. 11, firstly, the surface of the $\mathrm{K}-\mathrm{Fe}_{2} \mathrm{O}_{3}$ catalysts produced induced electrons and photo-induced holes under visible light irradiation (eqn (10)). Secondly, the aggregated electrons reacted with $\mathrm{S}_{2} \mathrm{O}_{8}{ }^{2-}$ to produce $\mathrm{SO}_{4}{ }^{--}$and ferric ions in aqueous solution activated $\mathrm{S}_{2} \mathrm{O}_{8}{ }^{2-}$ to produce $\mathrm{SO}_{4}{ }^{--}$(eqn (11) and (12)). Thirdly, $\mathrm{SO}_{4}{ }^{--}$could react with $\mathrm{H}_{2} \mathrm{O}$ to produce $\mathrm{OH}^{*}$ radicals (eqn (13)) which further accelerate the degradation reaction rate and improve the catalytic performance of the system. Finally, the produced radicals with strong oxidizing properties would attack organic pollutants to degrade it and then produce $\mathrm{CO}_{2}$ and $\mathrm{H}_{2} \mathrm{O}$ (eqn (14)). ${ }^{46}$

$$
\begin{gathered}
\text { Photocatalyst }+h \nu \rightarrow \mathrm{e}^{-}+\mathrm{h}^{+} \\
\mathrm{e}^{-}+\mathrm{S}_{2} \mathrm{O}_{8}{ }^{2-} \rightarrow \mathrm{SO}_{4}{ }^{2-}+\mathrm{SO}_{4}{ }^{--} \\
\mathrm{S}_{2} \mathrm{O}_{8}{ }^{2-}+\mathrm{Fe}^{2+} \rightarrow \mathrm{SO}_{4}{ }^{2-}+\mathrm{SO}_{4}{ }^{--}+\mathrm{Fe}^{3+} \\
\mathrm{SO}_{4}{ }^{--}+\mathrm{H}_{2} \mathrm{O} \rightarrow \mathrm{SO}_{4}{ }^{2-}+\mathrm{OH}^{\cdot}+\mathrm{H}^{+} \\
\cdot \mathrm{OH} \mathrm{SO}_{4}{ }^{--}+\text {organic pollutants } \rightarrow \mathrm{CO}_{2}+\mathrm{H}_{2} \mathrm{O}
\end{gathered}
$$

\section{Conclusions}

A K- $-\mathrm{Fe}_{2} \mathrm{O}_{3}$ photocatalyst was prepared by a facile method. In a K$\mathrm{Fe}_{2} \mathrm{O}_{3} / \mathrm{PS} /$ visible light system, a $99.8 \%$ degradation ratio of $\mathrm{RhB}$ was reached under optimal experimental conditions. The effects of catalyst dosage, PS concentration, RhB concentration and solution $\mathrm{pH}$ on the catalytic activity were researched. Most interestingly, we found that $\mathrm{K}-\mathrm{Fe}_{2} \mathrm{O}_{3}$ still showed high degradation activity for $\mathrm{RhB}$ over a wide range of $\mathrm{pH}(2.9-10)$. The practical application of the $\mathrm{K}-\mathrm{Fe}_{2} \mathrm{O}_{3} / \mathrm{PS} /$ visible light system for real dye wastewater remediation (MO, MB, $\mathrm{RhB}$ ) was also shown. On the other hand, the inhibition effects of inorganic anions on the system were observed. Furthermore, five cyclic runs showed that the catalyst had good stability and its chemical structure remained unchanged. Trapping experiments confirmed that $\mathrm{SO}_{4}{ }^{-{ }^{-}}$and $\cdot \mathrm{OH}$ were the main active radicals in the organic pollutant photodegradation process. Finally, we proposed a schematic mechanism for the degradation of 
organic pollutants in the $\mathrm{K}-\mathrm{Fe}_{2} \mathrm{O}_{3} / \mathrm{PS} /$ visible light system. This study has important value for practical organic wastewater treatment applications.

\section{Conflicts of interest}

There are no conflicts to declare.

\section{Acknowledgements}

This work was supported by Innovation Projects of Colleges and Universities in Guangdong Province (2018KTSCX249), the Zhaoqing City Science and Technology Innovation Guidance Project (2017S002) and the Innovative Entrepreneurship Project of Chinese College Students (201810580075, 201910580156).

\section{References}

1 K. Zhou, Q. Zhang, J. Li, B. Wang, S. Jiang and Y. Shi, RSC Adv., 2014, 4, 13205.

2 J. Ma, Y. Yang, X. Dai, Y. Chen, H. Deng, H. Zhou, S. Guo and G. Yan, Chemosphere, 2018, 190, 296-306.

3 S. Ganesh Babu, P. Aparna and G. Satishkumar, Ultrason. Sonochem., 2017, 34, 924-930.

4 Y.-J. Shih, T. B. Nguyen and C.-W. Chen, Chemosphere, 2016, 150, 294-303.

5 L. Chen, X. Peng, J. Liu, J. Li and F. Wu, Ind. Eng. Chem. Res., 2016, 51, 13632-13638.

6 D. Miao, J. Peng, X. Zhou, L. Qian, M. Wang and L. Zhai, Chemosphere, 2018, 207, 174-182.

7 H. Hori, A. Yamamoto, E. Hayakawa, S. Taniyasu, N. Yamashita and S. Kutsuna, Environ. Sci. Technol., 2005, 39, 2383-2388.

8 C. Qi, X. Liu, C. Lin, X. Zhang, J. Ma and H. Tan, Chem. Eng. J., 2014, 249, 6-14.

9 Y. F. Rao, L. Qu, H. Yang and W. Chu, J. Hazard. Mater., 2014, 268, 23-32.

10 D. Zhou, H. Zhang and L. Chen, J. Chem. Technol. Biotechnol., 2015, 90, 775-779.

11 P. Zhou, J. Zhang, J. Liu, Y. Zhang, J. Liang and Y. Liu, RSC Adv., 2016, 6, 99532-99539.

12 X. Zou, T. Zhou, J. Mao and X. Wu, Chem. Eng. J., 2014, 257, 36-44.

13 M. Nie, C. Yan, X. Xiong, X. Wen, X. Yang and Z. Lv, Chem. Eng. J., 2018, 348, 455-463.

14 C. Xiao, J. Li and G. Zhang, J. Cleaner Prod., 2018, 180, 550559.

15 G. Ran and Q. Li, RSC Adv., 2019, 9, 25414-25422.

16 Y. Hu, Y. Zhang and Y. Tang, RSC Adv., 2012, 2, 6036-6041.

17 L. Jiang, J. Wang, X. Wu and G. Zhang, Water, Air, Soil Pollut., 2017, 228, 463.

18 S. Yang and D. Che, RSC Adv., 2017, 7, 42233-42241.
19 L. Xu and J. Wang, Environ. Sci. Technol., 2012, 46, 1014510153.

20 S. Navalon, M. Alvaro and H. Garcia, Appl. Catal., B, 2010, 99, 1-26.

21 J. H. Ramirez, C. A. Costa, L. M. Madeira, et al., Appl. Catal., $B, 2007,71,44-56$.

22 G. T. Wei, Y. S. Li, L. Y. Zhang, Z. M. Li, Y. Deng and L. H. Shao, Clay Miner., 2017, 52, 439-451.

23 M. A. De León, M. Sergio, J. Bussi, et al., Environ. Sci. Pollut. Res., 2019, 26, 12720-12730.

24 J. Herney-Ramirez, M. Lampinen, M. A. Vicente, et al., Ind. Eng. Chem. Res., 2008, 47, 284-294.

25 H. Mao, K. Zhu, B. Li, C. Yao and Y. Kong, Appl. Surf. Sci., 2014, 292, 1009-1019.

26 T. Mishra and D. K. Mahato, J. Environ. Chem. Eng., 2016, 4, 1224-1230.

27 X. Zheng, et al., Chem. Eng. J., 2019, 374, 793-801.

28 K. N. D. S. Nascimento, M. C. A. D. Oliveira, P. S. Oliveira, et al., Fibers Polym., 2015, 16, 2177-2183.

29 H. Dong, Z. Li, X. Xu, Z. Ding and X. Fu, Appl. Catal., B, 2009, 89, 51-556.

30 Y. Guo, G. Zhang and H. Gan, J. Colloid Interface Sci., 2012, 369, 323-329.

31 P. Guo and X. Jin, Catal. Commun., 2018, 106, 101-105.

32 M. Zhou, H. Yang, T. Xian, R. S. Li, H. M. Zhang and X. X. Wang, J. Hazard. Mater., 2015, 289, 149-157.

33 G. Zhang, Y. Gao, Y. Zhang and Y. Guo, Environ. Sci. Technol., 2010, 44, 6384-6389.

34 H. Zhang, Z. Xiong, F. Ji, B. Lai and P. Yang, Chemosphere, 2017, 176, 192-201.

35 J. Ma, Q. Yang, Y. Wen and W. Liu, Appl. Catal., B, 2017, 201, 232-240.

36 S. Yang and D. Che, RSC Adv., 2017, 7, 42233-42241.

37 J. Ma, Y. Yang, X. Jiang, Z. Xie and H. Chen, Chemosphere, 2017, 190, 296-306.

38 H. Peng, W. Zhang, L. Xu, R. Fu and K. Lin, Chem. Eng. J., 2016, 306, 226-232.

39 C. Qi, X. Liu, J. Ma, C. Lin, X. Li and H. Zhang, Chemosphere, 2016, 151, 280-288.

40 K. Wang, G. Zhang, J. Li, Y. Li and X. Wu, ACS Appl. Mater. Interfaces, 2017, 50, 43704-43715.

41 J. Li, J. Wang, G. Zhang, Y. Li and K. Wang, Appl. Catal., B, 2018, 234, 167-177.

42 Y. Gao, H. Gan, G. Zhang and Y. Guo, Chem. Eng. J., 2013, 217, 221-230.

43 M. m. Ding, et al., J. Hazard. Mater., 2020, 382, 121064.

44 T. Guo, C. Dang, S. Tian, Y. Wang, D. Cao and Y. Gong, Chem.

Eng. J., 2018, 347, 535-542.

45 P. Hu and M. Long, Appl. Catal., B, 2016, 181, 103-117.

46 T. Y. Shang, L. H. Lu, Z. Cao, et al., Chem. Commun., 2019, 55, 5408-5419. 